\title{
Factors related to infertility in Brazil and their relationship with success rates after assisted reproduction treatment: an integrative review
}

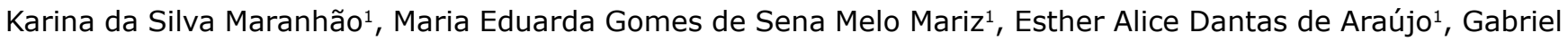
Ribeiro de Souza ${ }^{1}$, Karinna Veríssimo Meira Taveira ${ }^{1}$, Danielle Barbosa Morais ${ }^{1}$

\author{
${ }^{1}$ Department of Morphology, Federal University of Rio Grande do Norte, Natal, RN, Brazil
}

\begin{abstract}
This integrative review evaluated the most commonly diagnosed causes of infertility in men and women in Brazil, as well as the medically assisted reproduction technologies regularly employed in these cases. We searched in four electronic databases (PubMed, including Medline; Scopus; Web of Science and LILACS), and two grey literature (Google Scholar and OpenGrey), guided by the focused question: "What are the main factors responsible for male and female infertility in Brazil, and what are its relationships with success rates after assisted reproduction treatment?". We included interventional or observational studies, without limitation by language or year of publication. Our searches in the electronic indexers recovered 1,119 articles, and after analyzing the inclusion and exclusion criteria, 27 articles composed the body of analysis for this review. We grouped the studies into four themes: factors responsible for male and female infertility, assisted reproductive technologies (ART) used in the infertility treatment, assisted reproduction procedures, and clinical predictors of success rates in ART. Despite the scarcity of studies analyzing the association between infertility and assisted reproductive technologies in Brazil, it was possible to infer that the most prevalent infertility cause in women was endometriosis, while in men it was azoospermia. The most widely assisted reproductive technology applied in the country is the intracytoplasmic injection of spermatozoa (ICSI), ensuring better success rates in the treatment of infertility for men and women.
\end{abstract}

Keywords: male and female infertility, technologies of assisted reproduction, in vitro fertilization, intracytoplasmic sperm injection

\section{INTRODUCTION}

The World Health Organization (WHO) defines infertility as the inability of a couple to establish a clinical pregnancy after 12 months of regular unprotected sexual intercourse. Although commonly perceived as a female disorder, male factors are equally prevalent when considering the causes of infertility. Thus, it is estimated that female factors account for 35 to $40 \%$ of the causes of infertility, male factors for 20 to $40 \%$ and factors in which both have dysfunctions represent 20 to $30 \%$, as the other idiopathic causes, causing sterility without apparent cause (Nardelli et al., 2014; WHO, 2019; Zeqiraj et al., 2018).

Considering the treatment of infertile patients, assisted reproduction becomes an important alternative to try to make pregnancy possible to couples that have difficulty in conceiving naturally. Fertilization rates in Brazil show that the country's assisted reproduction services are effective, reaching international standards. Data from the $12^{\text {th }}$ report of the National System of Embryo Production (SisEmbrio) indicate that the average success rate in fertilization is $76 \%$, which is within the quality standards suggested in the international literature, ranging from $65 \%$ to $75 \%$ (SART, 2019; SisEmbrio, 2019).

Although intracytoplasmic sperm injection is one of the most widely used treatments, assisted reproductive techniques also include conventional in vitro fertilization, artificial insemination and methods for monitoring reproductive cycles; and the method or technique to be used is chosen according to the patient's clinical condition. However, little is known, about the most prevalent causes of infertility in Brazil and which treatment is the most appropriate for each case. Considering the importance of this knowledge to support decision making during the planning of an assisted reproduction treatment, the objective of this integrative review was to answer the focused question: "What are the main factors responsible for male and female infertility in Brazil, and its relationship with success rates after assisted reproduction treatment?"

\section{MATERIAL AND METHODS}

This integrative review covered the following stages: establishing the hypothesis and objectives of the integrative review; establishing the criteria for paper inclusion and exclusion (sample selection); defining the information to extract from the selected papers; evaluation of the studies included; interpretation of the results and synthesis of the studies. We used the PICO strategy to formulate the question addressed in this review, which is an acronym for Patient (or Population), Intervention, Comparison and Outcomes (Higgins et al., 2013).

This strategy allowed the identification of keywords, which helped locate relevant primary studies in the databases. Thus, the question that outlined the study was "What are the main factors responsible for male and female infertility in Brazil, and what is its relationship with the success rates after assisted reproduction treatment?" So, based on this question, the first element of the strategy $(P)$ consists on patients with infertility; the second (I) refers to the assisted reproduction treatments; the third element $(C)$, refers to the comparison of the interventions applied to the patients, and the fourth element $(\mathrm{O})$ deals with the technique's effectiveness.

\section{Inclusion criteria}

The inclusion criteria for the paper selection were: primary studies, conducted in Brazil; that cited infertility; which assisted reproduction treatment was employed; and the treatment outcome (whether there was pregnancy or not). There was no restriction regarding the time of publication or language. 


\section{Exclusion criteria}

We excluded papers based on the following criteria: (1) studies with animals; (2) treatments conducted in other countries; (3) studies that did not mention the infertility condition; (4) studies that did not mention the assisted reproductive technique employed; (5) studies that did not present the outcome of the treatment; (6) literature reviews, summaries, books, chapters of books, letters, opinion article, technical papers and guidelines.

\section{Information sources}

We conducted a computerized bibliographic search in four databases: PubMed (including Medline), Scopus, Web of Science and LILACS (Latin American and Caribbean Literature in Health Sciences), and two grey literature: Google Scholar and OpenGrey, for any references that might could have been missed. Additional information on search strategies is provided in Appendix 1. All searches were conducted on April 14, 2019.

\section{Search}

We combined the main descriptors related to the subjects we investigated, listed below, using the Boolean operators "AND" and "OR": "Assisted Reproductive Technology" OR "Assisted Reproductive Technologies" OR "Assisted Reproductive Technique" OR "Assisted Reproductive Techniques" OR "Assisted Reproductive Technic" OR "Assisted Reproductive Technics" AND "Brazil" (more details in Appendix 1).

We chose these keywords because they are associated with the object of study, and they belong to the catalog of PubMed descriptors (MESH Terms). We used the same keywords in LILACS, adding in this case their translations into Portuguese and Spanish, according to the Health Sciences Descriptors (DeCS).

We checked the references we obtained through the electronic search, and we removed the duplicates using the EndNote Web software (Thompson Reuters).

\section{Study selection and data collection process}

In the first phase, four independent reviewers selected the studies (K.S.M., M.A.G.S.M., E.A.D.A. and G.R.S.), they evaluated the titles and summaries of the articles we identified by the search strategy. At that stage, we sorted the articles according to the eligibility criteria established. We retained for further analysis of the full text those articles that generated questions and were potentially eligible. In the second phase, we fully read the studies selected by the four reviewers, which made it possible to exclude other articles because they did not meet the revision proposal. In the third phase, we extracted the main information of the articles and synthesized in summary tables, so that they could guide the critical analyses of the studies selected. We resolved the disagreements by discussion, consultation and guidance of a fifth reviewer (D.B.M.).

\section{Data items}

The data we collected included the year of publication, place of study/treatment, type of study (observational or interventional), infertility condition of the patient (men and women), assisted reproductive techniques employed in each case and the outcome of the treatment (if there was implantation, gestation and live births).

\section{Data synthesis}

We calculated the prevalence of each infertility condition dividing the number of times in which each condition was cited in the articles by the total number of conditions presented in this review, multiplying the result by 100 .

\section{RESULTS}

\section{Result selection}

Figure 1 depicts the bibliographic search process and the review selection criteria. The searches in the electronic databases and in the grey literature recovered 1,125 papers. After removing the duplicates, we evaluated 1,119 papers, and we excluded 916, resulting in 203 articles for full text reading. In this second step, we excluded 168 papers, because they did not meet the eligibility criteria. Thus, we included 27 remaining studies in the qualitative and quantitative synthesis.

\section{Characteristics of the studies}

Table 1 shows a summary of the characteristics of the studies included in this review. Through the categorized analysis of the 27 articles that composed the final sample, we found that all were published between 2003 and 2019. Of these, 4 were cross-sectional studies (Pasqualotto et al., 2003; Esteves \& Glina, 2005; Cota et al., 2012; Souza et al., 2017), 12 were cohort studies (Pinheiro et al., 2003; Borges et al., 2003; Glina et al., 2005; Pasqualotto et al., 2005; Romão et al., 2010; Semião-Francisco et al., 2010; Cota et al., 2012; Borges et al., 2013; Coelho Neto et al., 2015; Maia-Filho et al., 2015; Scheffer et al., 2017; Bercaire et al., 2018); 6 were case-control studies (Setti et al., 2011; Pasqualotto et al., 2012; Cavagna et al., 2012; Picinato et al., 2014; Donabela et al., 2015; Costa et al., 2016); 3 were case reports (Valle et al., 2012; Taitson et al., 2012; Borges et al., 2016) and 2 were randomized controlled trials (Geber \& Sampaio, 2013; Nastri et al., 2013).

In $15.21 \%$ of the articles included in this review, endometriosis is cited as the main condition causing female infertility (Cota et al., 2012; Nastri et al., 2013; Maia-Filho et al., 2015; Picinato et al., 2014; Donabela et al., 2015; Coelho Neto et al., 2015; 2016); and in $13.04 \%$ azoospermia is the male infertility condition (Pasqualotto et al., 2003; Glina et al., 2005; Esteves \& Glina, 2005; Pasqualotto et al., 2005; Semião-Francisco et al., 2010; Taitson et al., 2012). Figure 2 shows the other infertility conditions presented by the patients.

Regarding the assisted reproduction techniques, 7 studies $(25.92 \%)$ mentioned that patients were submitted to intracytoplasmic sperm injection (ICSI) or conventional in vitro fertilization (IVF) (Cota et al., 2012; Geber \& Sampaio, 2013; Coelho Neto et al., 2015; 2016; Costa et al., 2016; Souza et al., 2017; Bercaire et al., 2018); 18 studies (66.66\%) cited ICSI exclusively (Pinheiro et al., 2003; Borges et al., 2003; Pasqualotto et al., 2003; Glina et al., 2005; Esteves \& Glina, 2005; Pasqualotto et al., 2005; Romão et al., 2010; Semião-Francisco et al., 2010; Setti et al., 2011; Pasqualotto, et al., 2012; Valle et al., 2012; Taitson et al., 2012; Nastri et al., 2013; Picinato et al., 2014; Maia-Filho et al., 2015; Donabela et al., 2015; Borges et al., 2016; Scheffer et al., 2017); and 2 studies $(7.40 \%)$ cited the Intracytoplasmic Injection of Morphologically Selected Sperm (IMSI) (Cavagna et al., 2012; Borges et al., 2013). IVF was used mainly in cases associated with female infertility, such as endometriosis, poor ovarian response, polycystic ovary syndrome and advanced age. ICSI cycles were associated with cases similar to IVF, and causes related to the reduction in sperm count and/or quality. IMSI predominated in leukocytospermia conditions.

\section{DISCUSSION}

This integrative review investigated the main conditions of male and female infertility in Brazil, and their relationship with success rates after the treatment of assisted 


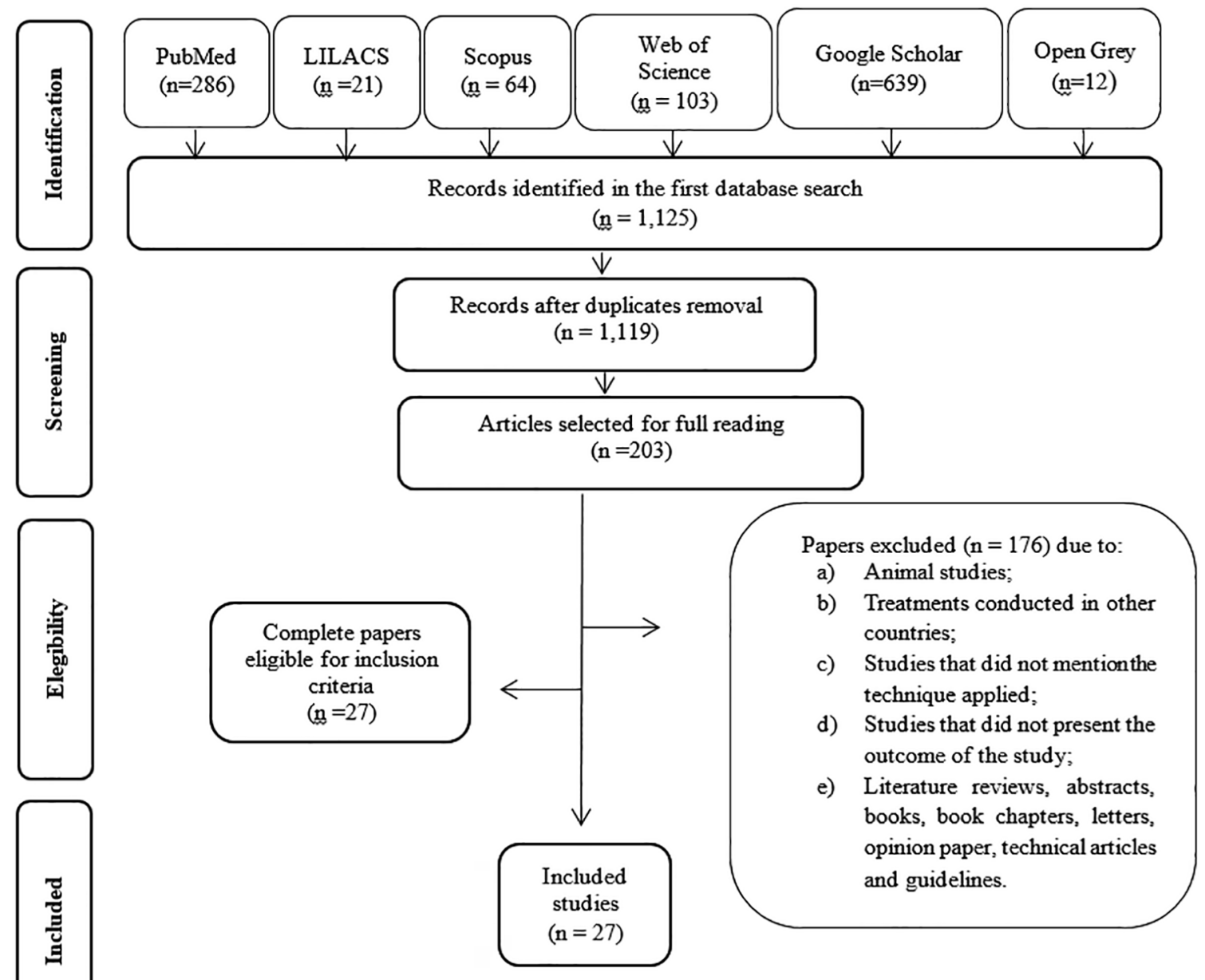

Figure 1. Flow diagram of literature search and selection criteria

reproduction. By our knowledge, it is the first to address this theme, allowing the compilation about the relations between such conditions and the assisted reproduction treatments employed in the country.

\section{Main factors responsible for female and male in- fertility \\ The main factors associated with female infertility in-} cluded endometriosis, tubal factor, polycystic ovary syndrome, endocrine/anovulatory and advanced age; while for males it included seminal alterations (azoospermia, oligozoospermia, asthenozoospermia and teratozoospermia), varicocele and infertility after vasectomy, and anatomical factors.

The most prevalent factor in women is endometriosis, which consists of having endometrial tissue outside the uterus, inducing a chronic inflammatory reaction and the formation of adhesions. In this pathology, the endometrial tissue is commonly lodged on the peritoneal surface, ovaries and rectovaginal septum. Endometriosis is increasing in women and has an important relationship with female infertility, since endometrial tissue even outside the uterus, continues to be stimulated monthly by the action of the menstrual cycle hormones. This leads to an inflammatory reaction, which consequently influences the hormonal regulation necessary for ovulation, as well as embryo implantation (Crosera et al., 2010; Nácul \& Spritzer, 2010).

The peritoneal tube factor is also an important cause of female infertility. Pelvic inflammatory diseases, especially those caused by Chlamydia trachomatis and Neisseria gonorrhoeae, are undoubtedly among the most common causes of functional loss of uterine tubes, besides other causes such as endometriosis - which leads to tubal infertility (Fernandes et al., 2014).

Despite advances in assisted reproduction, poor ovarian response (POR) to gonadotrophin stimulation remains a problem in fertility treatment, especially in IVF, where a large number of oocytes are desirable. Many protocols and adjuvant therapies have already been proposed for the treatment of bad responders; among them ANDRO-IVF, a new protocol that promotes intraovarian androgenization. The idea that testosterone could be useful to improve poor ovarian response is based on studies which suggest that androgens play an important role in the early stages of follicular development. Besides that, the increase in intraovarian concentration of androgens appears to raise the expression of Follicle-Stimulating Hormone (FSH) receptors in granulosa cells, increasing ovary sensitivity to FSH. Transdermal testosterone before the IVF cycle seems to increase the rate of pregnancy and births by decreasing the 
Table 1. Summary of descriptive characteristics and results of interest from the included studies $(n=27)$

\begin{tabular}{|c|c|c|c|c|c|}
\hline $\begin{array}{l}\text { Author, } \\
\text { year, place }\end{array}$ & $\begin{array}{l}\text { Kind of } \\
\text { study }\end{array}$ & $\begin{array}{l}\text { Infertility condition } \\
\text { presented by the } \\
\text { patient }\end{array}$ & $\begin{array}{l}\text { Assisted } \\
\text { reproductive } \\
\text { technique } \\
\text { employed }\end{array}$ & Purpose of the study & Conclusion \\
\hline $\begin{array}{l}\text { Bercaire et } \\
\text { al., 2018, } \\
\text { Brazil }\end{array}$ & Cohort & $\begin{array}{l}\text { Advanced maternal } \\
\text { age }\end{array}$ & IVF/ICSI & $\begin{array}{l}\text { To evaluate a new } \\
\text { protocol designed } \\
\text { to improve POR } \\
\text { through intra-ovarian } \\
\text { androgenization, from } \\
\text { the analysis of the } \\
\text { number of recovered } \\
\text { mature oocytes; } \\
\text { fertilization, abortion } \\
\text { and pregnancy rates. }\end{array}$ & $\begin{array}{l}\text { The use of transdermal } \\
\text { testosterone before } \\
\text { the IVF cycle seems } \\
\text { to increase the rates } \\
\text { of recovered oocytes, } \\
\text { pregnancy and births in } \\
\text { patients with POR. }\end{array}$ \\
\hline $\begin{array}{l}\text { Borges et al., } \\
2003 \text {, Brazil }\end{array}$ & Cohort & $\begin{array}{l}\text { Obstructive } \\
\text { azoospermia after } \\
\text { vasectomy }\end{array}$ & ICSI & $\begin{array}{l}\text { To evaluate the } \\
\text { relationship between } \\
\text { the period of post- } \\
\text { vasectomy and the } \\
\text { reproductive capacity } \\
\text { post ICSI. }\end{array}$ & $\begin{array}{l}\text { The interval between } \\
\text { vasectomy and sperm } \\
\text { recovery procedure has } \\
\text { no effect on outcome } \\
\text { until } 14 \text {-year interval. }\end{array}$ \\
\hline $\begin{array}{l}\text { Borges et al., } \\
2013 \text {, Brazil }\end{array}$ & Cohort & $\begin{array}{l}\text { Leukocytospermia } \\
\text { Tubal factor } \\
\text { Idiopathic }\end{array}$ & IMSI & $\begin{array}{l}\text { To compare IMSI results } \\
\text { between cycles in which } \\
\text { density gradient swim- } \\
\text { up or centrifugation } \\
\text { techniques were used } \\
\text { for sperm preparation. }\end{array}$ & $\begin{array}{l}\text { SUP and DGC } \\
\text { techniques recovered } \\
\text { improved sperm } \\
\text { fractions and promoted } \\
\text { similar IMSI results. }\end{array}$ \\
\hline $\begin{array}{l}\text { Borges et al., } \\
2016 \text {, Brazil }\end{array}$ & Case-report & $\begin{array}{l}\text { Oligozoospermia } \\
\text { Astenozoospermia } \\
\text { Teratozoospermia }\end{array}$ & ICSI & $\begin{array}{l}\text { To compare ICSI results } \\
\text { among groups with } \\
\text { different mobile sperm } \\
\text { count ranges, in couples } \\
\text { with male infertility. }\end{array}$ & $\begin{array}{l}\text { The total mobile sperm } \\
\text { count is not a reliable } \\
\text { predictor of ICSI result, } \\
\text { because it does not } \\
\text { consider morphology. } \\
\text { Therefore, it was not } \\
\text { able to predict ICSI } \\
\text { laboratory or clinical } \\
\text { results. }\end{array}$ \\
\hline $\begin{array}{l}\text { Cavagna et } \\
\text { al., 2012, } \\
\text { Brazil }\end{array}$ & $\begin{array}{l}\text { Case-con- } \\
\text { trol }\end{array}$ & Leukocytospermia & IVF/IMSI & $\begin{array}{l}\text { To analyze ICSI } \\
\text { and IMSI results in } \\
\text { couples in whom the } \\
\text { male partner had } \\
\text { leukocytospermia. }\end{array}$ & $\begin{array}{l}\text { The results indicate that } \\
\text { leukocytospermia may } \\
\text { not have a negative } \\
\text { effect on ICSI or IMSI } \\
\text { cycle results. }\end{array}$ \\
\hline $\begin{array}{l}\text { Coelho Neto } \\
\text { et al., 2015, } \\
\text { Brazil }\end{array}$ & Cohort & $\begin{array}{l}\text { Endometrioma } \\
\text { Thin endometrium } \\
\text { Poor ovarian response }\end{array}$ & IVF/ICSI & $\begin{array}{l}\text { To analyze whether } \\
\text { endometrial thickness } \\
\text { and the presence of } \\
\text { endometrioma are } \\
\text { independent predictors } \\
\text { of clinical pregnancy } \\
\text { rate or simply } \\
\text { associated with POR. }\end{array}$ & $\begin{array}{l}\text { Both thin endometrium } \\
\text { and the presence of } \\
\text { endometrioma are } \\
\text { associated with poor } \\
\text { ovarian response, } \\
\text { but are not important } \\
\text { independent predictors } \\
\text { of clinical pregnancy. }\end{array}$ \\
\hline $\begin{array}{l}\text { Coelho Neto } \\
\text { et al., 2016, } \\
\text { Brazil }\end{array}$ & Cohort & Endometriosis & IVF/ICSI & $\begin{array}{l}\text { To evaluate whether } \\
\text { women with } \\
\text { endometriosis have } \\
\text { different ovarian } \\
\text { reserves and } \\
\text { reproductive outcomes } \\
\text { as compared to women } \\
\text { without such diagnosis } \\
\text { submitted to IVF and } \\
\text { ICSI. }\end{array}$ & $\begin{array}{l}\text { Women diagnosed with } \\
\text { endometriosis are more } \\
\text { likely to have deficient } \\
\text { ovarian reserve; } \\
\text { however, their chance } \\
\text { of conceiving by IVF/ } \\
\text { ICSI is similar to that } \\
\text { seen in patients without } \\
\text { endometriosis and with } \\
\text { a comparable ovarian } \\
\text { reserve. }\end{array}$ \\
\hline $\begin{array}{l}\text { Costa et al., } \\
2016, \text { Brazil }\end{array}$ & $\begin{array}{l}\text { Case- } \\
\text { control }\end{array}$ & Idiopathic & IVF/ICSI & $\begin{array}{l}\text { To investigate the } \\
\text { genetic diversity of the } \\
\text { HLA-G gene and its } \\
\text { influence on infertility, } \\
\text { and the result after } \\
\text { assisted reproduction } \\
\text { treatment in women } \\
\text { with and without } \\
\text { pregnancy success. }\end{array}$ & $\begin{array}{l}\text { Some HLA-G alleles } \\
\text { have been associated } \\
\text { with reproductive } \\
\text { failure. }\end{array}$ \\
\hline
\end{tabular}


Continuation Table 1.

\begin{tabular}{|c|c|c|c|c|c|}
\hline $\begin{array}{l}\text { Cota et al., } \\
\text { 2012, Brazil }\end{array}$ & $\begin{array}{l}\text { Cross- } \\
\text { sectional }\end{array}$ & $\begin{array}{l}\text { Endometriosis } \\
\text { Ovary polycystic syn- } \\
\text { drome }\end{array}$ & IVF/ICSI & $\begin{array}{l}\text { To investigate whether } \\
\text { the prevalence of } \\
\text { oocyte dysmorphism is } \\
\text { influenced by the type } \\
\text { of pituitary suppression } \\
\text { used in ovarian } \\
\text { stimulation. }\end{array}$ & $\begin{array}{l}\text { In terms of oocyte } \\
\text { morphology quality, } \\
\text { there is no difference } \\
\text { between the multiple } \\
\text { dose protocol of the } \\
\text { antagonist and the } \\
\text { long-term agonist } \\
\text { protocol. }\end{array}$ \\
\hline $\begin{array}{l}\text { Donabela et } \\
\text { al., 2015, } \\
\text { Brazil }\end{array}$ & $\begin{array}{l}\text { Case- } \\
\text { control }\end{array}$ & Endometriosis & ICSI & $\begin{array}{l}\text { To compare the } \\
\text { expression of SOD1, } \\
\text { SOD2 and GPX4 in } \\
\text { mature oocyte CCS } \\
\text { from infertile women } \\
\text { and investigate the } \\
\text { interaction between } \\
\text { the expression of these } \\
\text { genes and clinical } \\
\text { pregnancy. }\end{array}$ & $\begin{array}{l}\text { Only infertile women } \\
\text { with moderate/ } \\
\text { severe endometriosis } \\
\text { had increased } \\
\text { SOD1 expression } \\
\text { incumuluscells, } \\
\text { compared to women } \\
\text { with minimal/mild } \\
\text { endometriosis and } \\
\text { controls, with positive } \\
\text { interaction between } \\
\text { increased expression } \\
\text { and occurrence of } \\
\text { clinical pregnancy. }\end{array}$ \\
\hline $\begin{array}{l}\text { Esteves \& } \\
\text { Glina, 2005, } \\
\text { Brazil }\end{array}$ & $\begin{array}{l}\text { Cross- } \\
\text { sectional }\end{array}$ & Azoospermia & ICSI & $\begin{array}{l}\text { To analyze if testicular } \\
\text { histological patterns in } \\
\text { a group of azoospermic } \\
\text { men with varicocele } \\
\text { are predictive of the } \\
\text { result of treatment after } \\
\text { correction of subinguinal } \\
\text { microsurgical varicocele. }\end{array}$ & $\begin{array}{l}\text { Microsurgical repair } \\
\text { of varicocele in men } \\
\text { with non-obstructive } \\
\text { azoospermia may result } \\
\text { in the appearance of } \\
\text { spermatozoa in the } \\
\text { ejaculate, when there is } \\
\text { hypo spermatogenesis } \\
\text { or cessation of } \\
\text { maturation in the } \\
\text { testicular histological } \\
\text { diagnosis. }\end{array}$ \\
\hline $\begin{array}{l}\text { Geber \& } \\
\text { Sampaio, } \\
\text { 2013, Brazil }\end{array}$ & $\begin{array}{l}\text { Randomized } \\
\text { controlled } \\
\text { trial }\end{array}$ & Male factor & ICSI/IVF & $\begin{array}{l}\text { To evaluate whether } \\
\text { the prolonged action } \\
\text { of GnRH in the } \\
\text { luteal phase, in the } \\
\text { assisted reproductive } \\
\text { treatment cycles, } \\
\text { affects the pregnancy } \\
\text { rates according to the } \\
\text { duration of its action in } \\
\text { this phase. }\end{array}$ & $\begin{array}{l}\text { Regardless the GnRH } \\
\text { action duration in the } \\
\text { luteal phase, there } \\
\text { was no significant } \\
\text { association with } \\
\text { pregnancy rates. }\end{array}$ \\
\hline $\begin{array}{l}\text { Glina et al., } \\
2005 \text {, Brazil }\end{array}$ & Cohort & $\begin{array}{l}\text { Obstructive azoosper- } \\
\text { mia }\end{array}$ & ICSI & $\begin{array}{l}\text { To evaluate the rate of } \\
\text { sperm recovery in each } \\
\text { of the histopathological } \\
\text { groups: } \\
\text { hypospermatogenesis- } \\
\text { hypo; maturation arrest } \\
\text { on spermatogenesis- } \\
\text { MA; and single Sertoli } \\
\text { cell-SSO. }\end{array}$ & $\begin{array}{l}\text { There were sperm } \\
\text { cells in } 33 \% \text { of the } \\
\text { procedures in patients } \\
\text { with MA, } 50 \% \text { in } \\
\text { patients with hypo and } \\
40 \% \text { of the procedures } \\
\text { in patients with SSO. }\end{array}$ \\
\hline $\begin{array}{l}\text { Maia-Filho } \\
\text { et al., 2015, } \\
\text { Brazil }\end{array}$ & Cohort & $\begin{array}{l}\text { Male factor } \\
\text { Endometriosis } \\
\text { Tubal factor } \\
\text { Ovulatory factor } \\
\text { Idiopathic }\end{array}$ & ICSI & $\begin{array}{l}\text { To evaluate the } \\
\text { expression of } \\
\text { endometrial matrix } \\
\text { metalloproteinases } \\
\text { (MMPs) } 2 \text { and } 9 \text { and } \\
\text { E-cadherin in the peri- } \\
\text { implantation phase } \\
\text { of infertile women } \\
\text { undergoing IVF cycles. }\end{array}$ & $\begin{array}{l}\text { MMP-2, MMP-9 } \\
\text { and E-cadherin are } \\
\text { expressed in the } \\
\text { endometrium of infertile } \\
\text { women during the } \\
\text { receptive phase of the } \\
\text { natural menstrual cycle. } \\
\text { However, there is no } \\
\text { correlation between } \\
\text { the expression of these } \\
\text { molecules and IVF } \\
\text { clinical results. }\end{array}$ \\
\hline
\end{tabular}


Continuation Table 1.

\begin{tabular}{|c|c|c|c|c|c|}
\hline $\begin{array}{l}\text { Nastri et al., } \\
\text { 2013, Brazil }\end{array}$ & $\begin{array}{l}\text { Randomized } \\
\text { controlled } \\
\text { trial }\end{array}$ & Endometrial factor & ICSI & $\begin{array}{l}\text { To investigate the effect } \\
\text { of endometrial injury on } \\
\text { reproductive outcomes } \\
\text { and to evaluate the } \\
\text { pain involved in } \\
\text { the procedure for } \\
\text { women undergoing } \\
\text { assisted reproduction } \\
\text { techniques. }\end{array}$ & $\begin{array}{l}\text { The rates of } \\
\text { implantation, birth } \\
\text { and clinical pregnancy } \\
\text { were higher in } \\
\text { patients submitted to } \\
\text { endometrial injury. } \\
\text { However, there were } \\
\text { reports of considerable } \\
\text { pain during the } \\
\text { procedure. }\end{array}$ \\
\hline $\begin{array}{l}\text { Pasqualotto } \\
\text { et al., 2005, } \\
\text { Brazil }\end{array}$ & Cohort & Azoospermia & ICSI & $\begin{array}{l}\text { To evaluate the } \\
\text { fertilization, pregnancy } \\
\text { and miscarriage } \\
\text { rates post- ICSI, with } \\
\text { epididymal or testicular } \\
\text { spermatozoa in different } \\
\text { types of azoospermia. }\end{array}$ & $\begin{array}{l}\text { Although there were } \\
\text { no differences in } \\
\text { the evaluated rates, } \\
\text { fertilization and } \\
\text { implantation, rates were } \\
\text { higher in patients with } \\
\text { congenital blockage of } \\
\text { the seminal pathway. } \\
\text { The rate of pregnancy } \\
\text { was higher, and the rate } \\
\text { of miscarriage was lower } \\
\text { when epididymis sperm } \\
\text { was used compared to } \\
\text { testicular sperm. }\end{array}$ \\
\hline $\begin{array}{l}\text { Pasqualotto } \\
\text { et al., 2003, } \\
\text { Brazil }\end{array}$ & $\begin{array}{l}\text { Cross-sec- } \\
\text { tional }\end{array}$ & $\begin{array}{l}\text { Obstructive azoosper- } \\
\text { mia } \\
\text { Vasectomy } \\
\text { Bilateral absence con- } \\
\text { genital vas deferens }\end{array}$ & ICSI & $\begin{array}{l}\text { To evaluate the } \\
\text { effectiveness of } \\
\text { repeated PESA } \\
\text { procedures. }\end{array}$ & $\begin{array}{l}\text { The procedures were } \\
\text { effective in more } \\
\text { than one-third of } \\
\text { the repeated PESA } \\
\text { attempts, resulting in } \\
\text { the presence of mobile } \\
\text { spermatozoa. }\end{array}$ \\
\hline $\begin{array}{l}\text { Pasqualotto } \\
\text { et al., 2012, } \\
\text { Brazil }\end{array}$ & $\begin{array}{l}\text { Case-con- } \\
\text { trol }\end{array}$ & Varicocele & ICSI & $\begin{array}{l}\text { To evaluate the effect } \\
\text { of varicocelectomy } \\
\text { on sperm quality and } \\
\text { gestation rate after } \\
\text { ICSI. }\end{array}$ & $\begin{array}{l}\text { Although varicocelectomy } \\
\text { should always be } \\
\text { performed before } \\
\text { assisted reproduction, } \\
\text { this procedure does not } \\
\text { increase pregnancy rates } \\
\text { or decrease miscarriage } \\
\text { rates after ICSI. }\end{array}$ \\
\hline $\begin{array}{l}\text { Picinato et } \\
\text { al., 2014, } \\
\text { Brasil }\end{array}$ & $\begin{array}{l}\text { Case-con- } \\
\text { trol }\end{array}$ & $\begin{array}{l}\text { Endometriosis } \\
\text { Anovulation } \\
\text { Tubal factor } \\
\text { Idiopathic male factor }\end{array}$ & ICSI & $\begin{array}{l}\text { To examine the effects } \\
\text { of oocyte submission to } \\
\text { PM before ICSI. }\end{array}$ & $\begin{array}{l}\text { PM was associated with } \\
\text { increased fertilization } \\
\text { rates, and reduced } \\
\text { cleavage rate and } \\
\text { number of high-quality } \\
\text { embryos. }\end{array}$ \\
\hline $\begin{array}{l}\text { Pinheiro et } \\
\text { al., 2003, } \\
\text { Brazil }\end{array}$ & Cohort & Male factor & ICSI & $\begin{array}{l}\text { To determine } \\
\text { implantation and } \\
\text { pregnancy rates in } \\
\text { patients submitted } \\
\text { to ICSI and treated } \\
\text { with beta2-adrenergic } \\
\text { agonists, considering } \\
\text { the uterine-relaxing } \\
\text { action of these agents. }\end{array}$ & $\begin{array}{l}\text { Pregnancy and } \\
\text { implantation rates did } \\
\text { not differ significantly } \\
\text { between the groups. In } \\
\text { addition, there were no } \\
\text { significant differences in } \\
\text { miscarriage rates. }\end{array}$ \\
\hline $\begin{array}{l}\text { Romão et al., } \\
\text { 2010, Brazil }\end{array}$ & Cohort & $\begin{array}{l}\text { Male factor } \\
\text { Tubal factor } \\
\text { Ovulatory factor } \\
\text { Uterine factor }\end{array}$ & ICSI & $\begin{array}{l}\text { To assess the impact } \\
\text { of the average } \\
\text { oocyte diameter } \\
\text { on the occurrence } \\
\text { of fertilization and } \\
\text { embryonic quality in } \\
\text { assisted reproduction } \\
\text { cycles. }\end{array}$ & $\begin{array}{l}\text { The diameter of mature } \\
\text { oocytes does not } \\
\text { appear to be related } \\
\text { to fertilization or the } \\
\text { quality of human } \\
\text { embryos development } \\
\text { on days } 2 \text { and } 3 \text { after } \\
\text { ICSI. }\end{array}$ \\
\hline
\end{tabular}


Continuation Table 1.

\begin{tabular}{|c|c|c|c|c|c|}
\hline $\begin{array}{l}\text { Scheffer } \\
\text { et al., 2017, } \\
\text { MG/Brazil }\end{array}$ & Cohort & $\begin{array}{l}\text { Advanced maternal } \\
\text { age }\end{array}$ & ICSI & $\begin{array}{l}\text { To evaluate embryonic } \\
\text { quality associations } \\
\text { and follicular reserve } \\
\text { markers, such as age, } \\
\text { FSH and AMH. }\end{array}$ & $\begin{array}{l}\text { Age is predictive } \\
\text { of the number of } \\
\text { oocytes collected and } \\
\text { of embryonic quality, } \\
\text { factors that influences } \\
\text { the outcome of } \\
\text { assisted reproductive } \\
\text { technologies. }\end{array}$ \\
\hline $\begin{array}{l}\text { Semião-Fran- } \\
\text { cisco et al., } \\
\text { 2010, Brazil }\end{array}$ & Cohort & Azoospermia & ICSI & $\begin{array}{l}\text { To compare ICSI results } \\
\text { among patients with } \\
\text { OA or NOA submitted } \\
\text { to TESA and PESA } \\
\text { procedures. }\end{array}$ & $\begin{array}{l}\text { There were no } \\
\text { statistically significant } \\
\text { differences in } \\
\text { clinical pregnancy or } \\
\text { implantation rates } \\
\text { among patients } \\
\text { submitted to TESA and } \\
\text { PESA. }\end{array}$ \\
\hline $\begin{array}{l}\text { Setti et al., } \\
\text { 2011, Brazil }\end{array}$ & $\begin{array}{l}\text { Case- } \\
\text { control }\end{array}$ & Poor ovarian response & ICSI & $\begin{array}{l}\text { To test the hypothesis } \\
\text { that women of } \\
\text { advanced age and } \\
\text { with POR have an } \\
\text { increase in embryo with } \\
\text { chromosomal changes } \\
\text { when compared to } \\
\text { elderly women, who } \\
\text { presented a normal } \\
\text { ovarian response. }\end{array}$ & $\begin{array}{l}\text { Women of advanced } \\
\text { age and with POR to } \\
\text { gonadotrophins are } \\
\text { not at increased risk } \\
\text { of producing aneuploid } \\
\text { embryosin vitro. }\end{array}$ \\
\hline $\begin{array}{l}\text { Souza et al., } \\
\text { 2017, Brazil }\end{array}$ & $\begin{array}{l}\text { Cross- } \\
\text { sectional }\end{array}$ & Poor ovarian response & IVF/ICSI & $\begin{array}{l}\text { To investigate the } \\
\text { impact of follicular } \\
\text { washing on the number } \\
\text { of oocytes recovered, } \\
\text { oocyte maturity, rate of } \\
\text { fertilization, embryonic } \\
\text { development and } \\
\text { pregnancy rate in POR } \\
\text { women. }\end{array}$ & $\begin{array}{l}\text { Follicular lavage may } \\
\text { be an appropriate } \\
\text { alternative to increasing } \\
\text { the number of oocytes } \\
\text { and pregnancy rates in } \\
\text { patients with POR. }\end{array}$ \\
\hline $\begin{array}{l}\text { Taitson et al., } \\
\text { 2012, Brazil }\end{array}$ & Case report & $\begin{array}{l}\text { Obstructive azoosper- } \\
\text { mia }\end{array}$ & ICSI & $\begin{array}{l}\text { To evaluate the } \\
\text { effectiveness of PESA in } \\
\text { an azoospermic } 81 \text {-year } \\
\text { old patient. }\end{array}$ & $\begin{array}{l}\text { The procedure } \\
\text { was effective, with } \\
\text { pregnancy and birth of } \\
\text { two babies. }\end{array}$ \\
\hline $\begin{array}{l}\text { Valle et al., } \\
\text { 2012, Brazil }\end{array}$ & Case report & $\begin{array}{l}\text { Ovarian failure } \\
\text { Idiopathic }\end{array}$ & ICSI & $\begin{array}{l}\text { To demonstrate that } \\
\text { human embryos can be } \\
\text { successfully vitrified/ } \\
\text { heated twice in the } \\
\text { cleavage phase. }\end{array}$ & $\begin{array}{l}\text { Human embryos } \\
\text { can be successfully } \\
\text { vitrified/heated twice } \\
\text { in the cleavage phase, } \\
\text { being able to promote } \\
\text { successful pregnancies } \\
\text { and deliveries. }\end{array}$ \\
\hline
\end{tabular}

AMH: Anti-Mullerian Hormone; DGC: Density Gradient Centrifugation; FSH:Follicle-Stimulating Hormone; GnRH: Gonadotropin Releasing Hormone; HLA-G: G-Human Leukocyte Antigen; IVF: In Vitro Fertilization; ICSI: Intracytoplasmic Sperm Injection; IMSI: Intracytoplasmic Injection of Morphologically Selected Sperm; NOA: Non-obstructive azoospermia; OA: Obstructive azoospermia; PESA: Percutaneous Epididymal Sperm Aspiration; PM: Polarization Microscopy; POR: Poor Ovarian Response; SCO: Sertoli Cell-Only; SOD: Superoxide Dismutase; SUP: Swim-up; TESA: Testicular Sperm Aspiration.

required dose of gonadotropin, as well as the number of days of stimulation. Although these studies are still scarce, they have been promising, bringing new possibilities of adjuvant treatment to patients with low response to ovarian stimulation (Setti et al., 2011; Borges et al., 2013).

Polycystic ovary syndrome (POS) is the main gynecological endocrinopathy in women of reproductive age, and it is the most common cause of infertility due to anovulation. This endocrinopathy occurs in the ovaries from an imbalance in hormonal levels of androgens and insulin, causing the formation of ovarian cysts, which can interfere with the ovulation process. In this case, the patient does not ovulate properly and, therefore, may present long intervals between menstrual cycles, and may remain without menstruation for months, thus leading to infertility (Santana et al., 2008).

Advanced maternal age is also an important factor associated with female infertility, since natural fecundity and pregnancy rates decline with increasing age. This is due to significant reductions in the number and quality of the oocytes, since women are born with a limited pool of oocytes, which degenerate throughout their lives at each menstrual cycle. However, the main factor in the etiology of age-related female infertility is the decline in oocyte quality, since older women have higher rates of single chromatid abnormalities in oocytes, as well as chromosomal aneuploidies (Scheffer et al., 2017). 


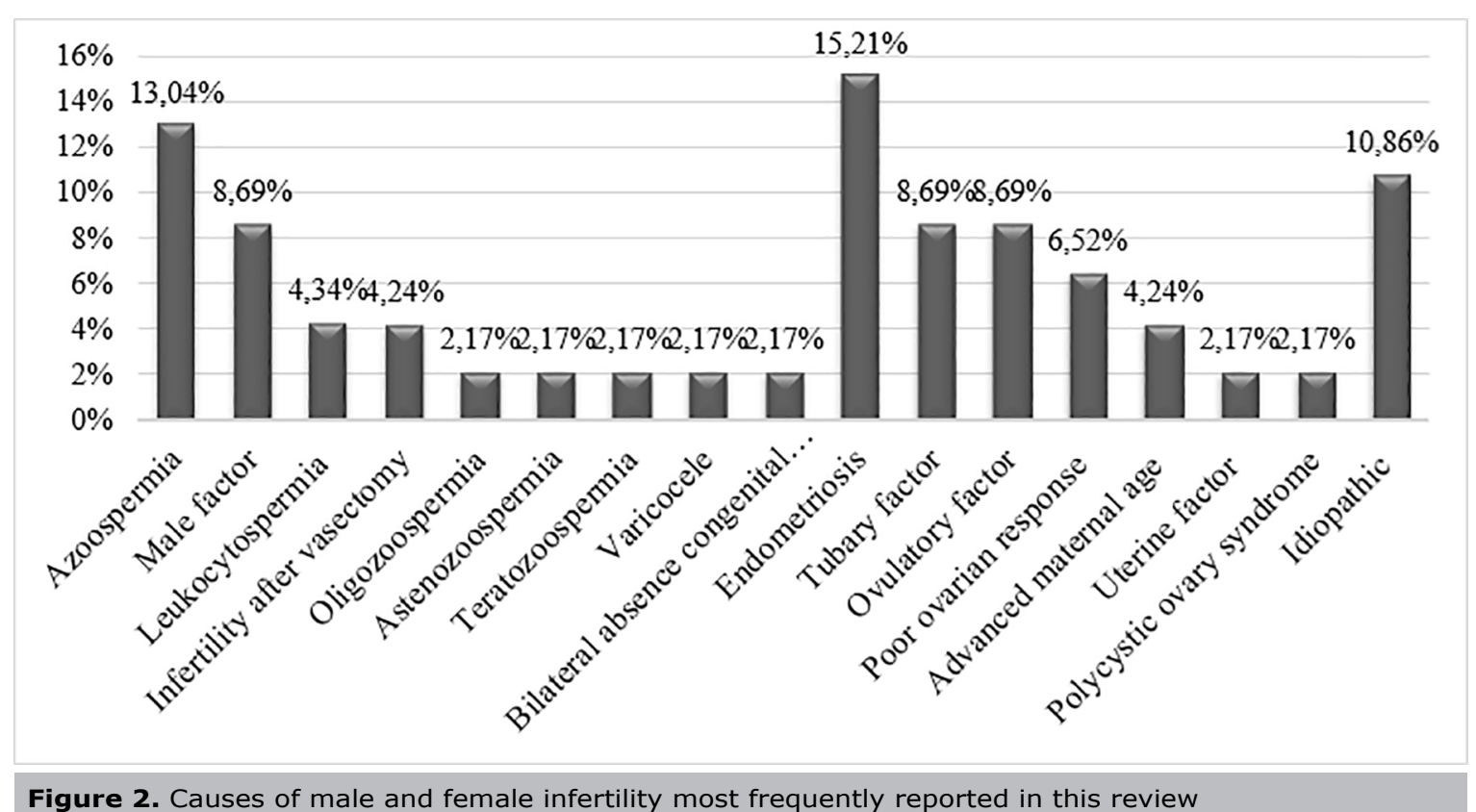

Figure 2. Causes of male and female infertility most frequently reported in this review

Azoospermia was the most prevalent factor in men, which consists of the absence of sperm in the semen. It is classified as obstructive or excretory azoospermia (OA), in cases where production is normal, but there is excretory pathway obstruction (epididymis, deferent or ejaculatory duct); vasectomy is the main example, and non-obstructive or secretory azoospermia (NOA), when there is testicular failure leading to the abolition of sperm production. In combination, there is azoospermia in approximately $10 \%$ of men with infertility (Harris \& Sandlow, 2008; Vieira et al., 2009).

Seminal alterations, such as azoospermia (Pasqualotto et al., 2003; Glina et al., 2005; Esteves \& Glina, 2005; Pasqualotto et al., 2005; Semião-Francisco et al., 2010; Taitson et al., 2012), oligozoospermia (Borges et al., 2016), asthenozoospermia (Borges et al., 2016) and teratozoospermia (Borges et al., 2016) were the most frequently cited infertility conditions in this review, and refer to abnormalities in sperm number, motility and morphology. Azoospermic men do not have sperm in their ejaculate, while in oligozoospermia there is a reduction in the amount of sperm present in the ejaculated fluid. In asthenozoospermia, there is a decreased spermatozoa motility, which can cause the inability or difficulty for sperm to fertilize the oocyte, while in teratozoospermia there is a large percentage of abnormally shaped sperm. There are morphology defects in different parts of the sperm: head, intermediate part and tail, which may render the natural fertilization, process impossible (Zegers-Hochschild et al., 2017).

Varicoceles are also an important cause of male infertility, being a condition that involves dilations and crooked veins of the pampiniform plexus, which drain blood from the testicles. Such alterations cause changes in temperature, oxygenation, nutrition and release of free radicals in testicular cells, which may compromise spermatogenesis and, consequently, cause male infertility (Cocuzza, 2011).

Another condition associated with male infertility is post-vasectomy infertility, a form of obstructive azoospermia, caused by the ligation of the deferent ducts in man. In these cases, men become infertile due to interruptions in sperm transit. However, given the widespread use of vasectomy as a method of contraception, there is a growing demand for vasovasostomy, which consists of surgical reversal, in which the two separate parts of the deferent duct are reconnected. ICSI combined with percutaneous epididymis sperm aspiration (PESA), or testicular sperm aspiration (TESA) is currently a widely used approach for fertility restoration in post-vasectomy cases, where anastomosis has failed. However, there is a relationship between the post-vasectomy period and the reproductive capacity of spermatozoa, that is, the shorter it is, the higher the chances of fertility return by ICSI. The rates of pregnancy and implants decrease significantly when sperm recovery is performed 14 years after surgery (Borges et al., 2003).

The articles included in this revision also mentioned infertility caused by anatomic factors, such as the congenital bilateral absence of the deferential duct, an anomaly responsible for approximately $6 \%$ of the cases of obstructive azoospermia, and for $1-2 \%$ of the cases of infertility in men (Bernardino et al., 2003).

Assisted reproductive technologies most commonly used in infertility treatment

Five techniques stand out today in medically assisted reproduction: intrauterine insemination (IUI), IVF, ICSI and IMSI. IUI is a simple procedure of three steps: follow-up of natural follicular development, semen collection and processing and artificial insemination through a catheter. IVF, in turn, is based on the collection of gametes, which are placed in contact on the same culture plate, and the sperm will then fertilize the oocyte outside the female body. After embryo fertilization and cultivation in the laboratory, it is transferred to the uterus. ICSI is a variant of IVF, in which we select a spermatozoon and inserted it into the oocyte cytoplasm with the help of a micromanipulator, surpassing the radiate crown and the zona pellucida, thus increasing fertilization rates. Finally, IMSI or super ICSI, is a technique that carefully selects sperm based on morphology, using a microscope that enables a magnification higher than 6,000 times, while in ICSI this increase is of $400 \mathrm{X}$, which, in the second case, does not enable the identification of some morphological abnormalities. However, IMSI is not used world widely anymore, because the technology offers no benefit over ICSI for live birth or miscarriage rates; although there is evidence that IMSI improves 
clinical pregnancy rates, this evidence is of very low quality (Santos, 2010; González-Ortega et al., 2010; Sermondade et al., 2011; Teixeira et al., 2020).

Among the AR technologies used in the country, ICSI is usually the main technique of choice, since it enables to solve the problems of infertility in most cases in which sperm quantity or motility is significantly reduced (Pasqualotto et al., 2003; Glina et al., 2005; Esteves \& Glina, 2005; Pasqualotto et al., 2005; Semião-Francisco et al., 2010; Taitson et al., 2012). The greatest advantage compared to other techniques is that fertilization is less affected by concentration, motility and/or sperm morphology, and its disadvantage is the high cost of the procedure. Therefore, ICSI is today the most used technique in cases where there are serious changes in seminal parameters (Nagy et al., 1995; Santos, 2010).

Considering the success rates achieved after the treatments employed, IVF was more effective in cases of infertility caused by advanced or profound endometriosis; in women with absence of uterine tubes or tubal lesions that prevented natural fertilization or artificial insemination, and in cases of idiopathic infertility. On the other hand, ICSI was effective in cases similar to conventional IVF, and in cases of severe male infertility, obstructive or non-obstructive, leading to absence of sperm in the ejaculate; in cases of varicocele, and in cases using cryopreserved samples.

\section{AR treatment procedures and their relationship with success rates}

In addition to these high complexity techniques, we employ several methods to obtain and process gametes, through complementary technologies and procedures that help increase gestational rates. We use sperm recovery methods, such as PESA and TESA, in conditions when the patient has azoospermia, either OA or NOA, with the goal of increasing fertilization rates in assisted reproduction treatments. These techniques are widely used in post-vasectomy infertility, when there is obstructive azoospermia, followed by ICSI, to achieve better success rates (Pasqualotto et al., 2003; Semião-Francisco et al., 2010; Taitson et al., 2012).

Sperm capacitation techniques, such as Swim-up (SUP) and density gradient centrifugation (DGC), which recovers fractions of high-quality sperm, are recommended to select spermatozoa with greater motility, by eliminating seminal plasma, which contains motility inhibitors, and immobile spermatozoa, along with immature cells and debris. Both sperm capacitating techniques are advantageous to be performed prior to assisted reproduction treatments, since the increase in spermatic motility favors penetration into the oocyte and, consequently, increases the fertilization rates (Borges et al., 2013).

On the other hand, follicular washing is a good alternative to enable a greater number of oocytes in patients with POR, since it improves the chances of overcoming the retention of oocytes in the follicle during direct aspiration or in the collection system, thus increasing the number of oocytes recovered (Souza et al., 2017).

Endometrial injury is an intentional damage to the endometrium by biopsy or curettage, which can induce decidualisation and increase the likelihood of implantation. This is because it induces a significant increase in the secretion of cytokines, interleukins, growth factors, macrophages and dendritic cells, which may be beneficial for the implantation of embryos and may lead to better synchronization between the endometrium and the embryo transfer, with a consequent increase in the rates of live births and clinical pregnancy. Overall, the results suggest a benefit from endometrial scratching. However, the studies have significant limitations; thus, the results may be biased. Therefore, it is not possible to say with any confidence whether endometrial injury can increase the probability of pregnancy. It is also important to consider potential adverse events of this procedure, including excessive pain and bleeding (Garris \& Garris, 2003; Li \& Hao, 2009; Lensen et al., 2016; Gnainsky et al., 2010; Nastri et al., 2012).

\section{Clinical predictors of success rates in assisted} reproductive technologies

The search for predictors of success in highly complex assisted reproductive treatments, such as IVF and ICSI, is essential, since it can determine the efficiency of the techniques and, consequently, the rates of gestational success. Among the predictors of success in the high-complexity assisted reproduction treatments discussed in this review, those who best determined the effectiveness of the techniques, as well as the rates of gestational success were: age, embryo quality and number of oocytes recovered, followed by two promising predictors: the HLA-G allele diversity profile and the SOD1 gene expression.

Maternal age is an important clinical predictor of success rates, since it is correlated to the number of oocytes collected and embryo quality, factors that influence the outcomes of assisted reproduction treatments. As age progresses, natural fecundity and pregnancy rates decline, which occurs due to a significant reduction in the number and quality of oocytes. However, the main factor in the etiology of age-related female infertility is the decline in oocyte quality, since older women have higher rates of single chromatid abnormalities in oocytes, as well as chromosomal aneuploidies (Scheffer et al., 2017).

We analyzed embryonic quality from studying the morphology of embryos and the way they evolved, until the $5^{\text {th }}$ or $6^{\text {th }}$ day after IVF procedures. Some of the parameters we assessed were oocyte shape, cellular fragmentation degree, number of blastomeres and their morphology, the presence of vacuoles and the first polar body ( $\left.1^{\text {st }} \mathrm{PB}\right)$. Regarding quality, the following factors yield bad prognosis: embryos with irregular cleavages, anuclear fragments, irregular blastomeres, low number of blastomeres, and absence of $1^{\text {st }} \mathrm{PB}$, which in turn may indicate that the oocyte is still immature or that it has already become post-mature, both unfit for insemination. The indicators of good prognosis include the occurrence of cleavage at the right time (leading to a suitable number of cells for the day of development; for example, the presence of embryos with 4 cells on day 2 and with 8 cells on day 3 ); harmonic and balanced cell division (leading to blastomere symmetry); absence of embryonic fragmentation; vacuole-free cytoplasm and signs of compaction (Araújo et al., 2008).

However, even embryos classified as being of good quality will not necessarily result in a clinical pregnancy, since endometrial health will be the determining factor. This is because endometrial receptivity disorders represent a potential source of implantation failure, even with good quality embryos. Embryonic implantation is a complex process that requires a synchronization between a healthy embryo and a receptive endometrium. This integrative capacity depends on several endocrine, paracrine and autocrine factors, which are responsible for endometrial receptivity. This is the period during which the epithelium of the endometrium acquires function, even transient, for blastocyst welcoming and implantation. This period is of extreme importance for implantation, since if the embryo reaches the endometrium or is transferred during IVF in a period outside the implantation window (either before or after), implantation will not occur (Martins, 2007; Tan et al., 2018).

The number of oocytes recovered is also an important prognostic variable, since there is a correlation between this number and treatment success rates. In Brazil, the 
average number of oocytes produced per woman is about 9.3. However, higher chances of success are obtained from IVF cycles with 15 oocytes recovered, with success rates of $65 \%$ of live births in women aging $18-34$ years; $50 \%$ in patients aging $35-37$ years; $47 \%$ of live births for women with 38 or 39 years old; and $35 \%$ of live births for women aged 40 or over. However, even with the average number of oocytes recovered below the considered "ideal", the average fertilization in Brazil reaches 76\% (Sunkara et al., 2011; SisEmbrio, 2019).

The human-G leukocyte antigen (HLA-G) encodes a protein class I (Ib), whose expression is intense in trophoblastic cells, and has therefore been recognized to confer immunological tolerance to the fetus. Some HLA-G alleles have been associated with increased or reduced expression of the levels of this protein, which have been associated with reproductive failure. However, it is still difficult to reach a consensus on the role of the different HLA-G alleles during pregnancy (Costa et al., 2016). However, it can be a promising clinical predictor, since identifying regulatory differences between alleles will not only improve our understanding of pregnancy biology, but it can also help unravel the immunogenic factors associated with infertility.

Although poorly explored, the gene expression evaluation in cumulus cells (CCS) of infertile women with endometriosis has been used to investigate the mechanisms involved in infertility associated with this disease. There is a greater expression of the SOD1 gene in infertile patients with moderate/severe endometriosis, when compared with healthy infertile patients or those with mild endometriosis. These results suggest an attempt to prevent oocyte oxidative damage triggered by the disease. Since only infertile women with moderate/severe endometriosis showed increased SOD1 expression in CCS compared to women with minimal/mild endometriosis and controls with positive interaction between increased expression and occurrence of clinical pregnancy, SOD1 may be a potential biomarker of clinical pregnancy, followed by ICSI (Donabela et al., 2015).

The birefringence analysis of the zona pellucida and visualization of the meiotic spindle under polarization microscopy (PM) are also clinical predictors, since they have correlation with implantation and pregnancy rates. These rates were significantly higher when transferring embryos derived from high refringence oocytes (HR), while miscarriage rates were higher when transferring embryos derived from low refringence oocytes (LR). Moreover, the fertilization rate was significantly lower when the meiotic spindle was not visible. However, a limitation of this technique is that while it may potentially increase these fertilization rates, this strategy may reduce the number of high-quality embryos, since the additional handling of the oocyte required to perform the $\mathrm{PM}$ is the main reason for this reduction (Picinato et al., 2014).

Despite the findings described here, this review had some methodological limitations, the main one being the scarcity of studies analyzing the association between infertility and assisted reproductive technologies in Brazil. Another possible limitation is that we did not include studies published on non-conventional and low-diffusion access bases, despite our effort using search strategies in a broad and careful way.

\section{CONCLUSION}

The qualitative and quantitative analysis of the studies that associated infertility and assisted reproductive technologies in Brazil showed that the main factors of female infertility were endometriosis, tubal factor, polycystic ovary syndrome, endocrine/anovulatory and advanced age, while males had reductions in sperm count and/or quality, infertility after vasectomy, varicocele and anatomical factors.
Regarding post-treatment success rates, they were associated with the assisted reproduction technologies chosen for each infertility condition, as well as the use of procedures such as PESA, TESA, follicular lavage and endometrial injury, which may result in better gestational rates when employed during assisted reproduction cycles.

ICSI has been the predominant technique employed and has proven to be the most promising for the treatment of female and male infertility.

\section{CONFLICT OF INTERESTS}

The authors declare that there are no conflicts of interest related to this study.

\section{Corresponding author:}

Danielle Barbosa Morais

Department of Morphology

Federal University of Rio Grande do Norte

Natal-RN, Brazil.

E-mail: daniellebmorais@gmail.com

\section{REFERENCES}

Araújo MCPM, Araújo CHM, Rocha MG, Martins WP, Reis RM, Ferriani RA, Navarro PAAS. First polar body morphology and fertilization rate, cleavage rate, and embryo quality. Rev Bras Ginecol Obstet. 2008;30:360-5 DOI: 10.1590/ S0100-72032008000700007.

Bercaire L, Nogueira SM, Lima PC, Alves VR, Donadio NF, Dzik A, Cavagna M, Fanchin R. ANDRO-IVF: a novel protocol for poor responders to IVF controlled ovarian stimulation. JBRA Assist Reprod. 2018;22:52-5. PMID: 29303236 DOI: $10.5935 / 1518-0557.20180011$

Bernardino ALF, Lima CE, Zatz MA. Analysis of mutations in the cystic fibrosis transmembrane regulator (CFTR) gene in patients with obstructive azoospermia. Genet Mol Biol. 2003;26:1-3. DOI: 10.1590/S1415-47572003000100001

Borges E Jr, Rossi-Ferragut LM, Pasqualotto FF, Rocha CC, Iaconelli A Jr. Different intervals between vasectomy and sperm retrieval interfere in the reproductive capacity from vasectomized men. J Assist Reprod Genet. 2003;20:33-7 PMID: 12645866 DOI: 10.1023/a:1021210805867.

Borges E Jr, Setti AS, Vingris L, Figueira RCS, Braga DPAF, Iaconelli $A$ Jr. Intracytoplasmic morphologically selected sperm injection outcomes: the role of sperm preparation techniques. J Assist Reprod Genet. 2013;30:849-54. PMID: 23547020 DOI: 10.1007/s10815-013-9989-x

Borges E Jr, Setti AS, Braga DPAF, Figueira RCS, Iaconelli A Jr. Total motile sperm count has a superior predictive value over the WHO 2010 cut-off values for the outcomes of intracytoplasmic sperm injection cycles. Andrology. 2016;4:880-6. PMID: 27152971 DOI: 10.1111/andr.12199

Cavagna M, Oliveira JB, Petersen CG, Mauri AL, Silva LF, Massaro FC, Franco JG Jr. The influence of leukocytospermia on the outcomes of assisted reproductive technology. Reprod Biol Endocrinol. 2012;10:44. PMID: 22703930 DOI: $10.1186 / 1477-7827-10-44$

Cocuzza MAS. Impact of clinical varicocele on testis size, semen parameters and seminal reactive oxygen species levels in a proven fertile population [Thesis]. São Paulo: Faculty of Medicine, University of São Paulo; 2011. 
Coelho Neto MA, Martins WP, Lima ML, Barbosa MA, Nastri CO, Ferriani RA, Navarro PA. Ovarian response is a better predictor of clinical pregnancy rate following embryo transfer than is thin endometrium or presence of an endometrioma. Ultrasound Obstet Gynecol. 2015;46:501-5. PMID: 25914103 DOI: $10.1002 /$ uog. 14884

Coelho Neto MA, Martins WP, Luz CM, Jianini BT, Ferriani RA, Navarro PA. Endometriosis, Ovarian Reserve and Live Birth Rate Following In Vitro Fertilization/Intracytoplasmic Sperm Injection. Rev Bras Ginecol Obstet. 2016;38:21824 PMID: 27196950 DOI: 10.1055/s-0036-1584126.

Costa CH, Gelmini GF, Nardi FS, Roxo VM, Schuffner A, da Graça MB. HLA-G profile of infertile couples who underwent assisted reproduction treatment. Human Immunol. 2016;77:1179-86. PMID: 27615505 DOI: 10.1016/j.humimm.2016.09.002

Cota AM, Oliveira JB, Petersen CG, Mauri AL, Massaro FC, Silva LF, Nicoletti A, Cavagna M, Baruffi RL, Franco JG Jr. GnRH agonist versus $\mathrm{GnRH}$ antagonist in assisted reproduction cycles: oocyte morphology. Reprod Biol Endocrinol. 2012;10:33. PMID: 22540993 DOI: 10.1186/1477-7827-10-33

Crosera AMLV, Vieira CHF, Samama M, Martinhago CD, Ueno J. Treatment of endometriosis associated with infertility - a literature review. Femina. 2010;38:251-6.

Donabela FC, Meola J, Padovan CC, de Paz CC, Navarro PA. Higher SOD1 Gene Expression in Cumulus Cells From Infertile Women With Moderate and Severe Endometriosis. Reprod Sci. 2015;22:1452-60. PMID: 25947891 DOI: $10.1177 / 1933719115585146$

Esteves SC, Glina S. Recovery of spermatogenesis after microsurgical subinguinal varicocele repair in azoospermic men based on testicular histology. Int Braz J Urol. 2005;31:541-8. PMID: 16386122 DOI: 10.1590/s167755382005000600005

Fernandes LB, Arruda JT, Approbato MS, Garcia-Zapata MT. Chlamydia trachomatis and Neisseria gonorrhoeae infection: factors associated with infertility in women treated at a human reproduction public service. Rev Bras Ginecol Obstet. 2014;36:353-8. PMID: 25184348 DOI: 10.1590/ so100-720320140005009.

Garris DR, Garris BL. Cytomorphometric analysis and surface ultrastructure of developing decidua. Tissue Cell. 2003,35:23342. PMID: 12921706 DOI: 10.1016/s0040-8166(03)00036-3

Geber S, Sampaio M. Effect of duration of the GnRH agonists in the luteal phase in the outcome of assisted reproduction cycles. Gynecol Endocrinol. 2013;29:608-10. PMID: 23656392 DOI: 10.3109/09513590.2013.788635

Glina S, Soares JB, Antunes Jr N, Galuppo AG, Paz LB, Wonchockier R. Testicular histopathological diagnosis as a predictive factor for retrieving spermatozoa for ICSI in non-obstructive azoospermic patients. Int Braz J Urol. 2005;31:338-41. PMID: 16386130 DOI: $10.1590 /$ s167755382005000600013
Gnainsky Y, Granot I, Aldo PB, Barash A, Or Y, Schechtman $\mathrm{E}$, Mor G, Dekel N. Local injury of the endometrium induces an inflammatory response that promotes successful implantation. Fertil Steril. 2010;94:2030-6. PMID: 20338560 DOI: $10.1016 /$ j.fertnstert.2010.02.022

González-Ortega C, Cancino-Villarreal P, Pérez-Torres A, Vargas-Maciel MA, Martínez-Garza SG, Pérez-Peña E, Gutiérrez-Gutiédrrez AM. Intracytoplasmic morphologically selected sperm injection (IMSI) vs intracytoplasmic sperm injection (ICSI) in patients with repeated ICSI failure. Ginecol Obstet Mex. 2010;78:652-9. PMID: 21961371

Harris SE, Sandlow JI. Sperm acquisition in nonobstructive azoospermia: what are the options? Urol Clin North Am. 2008;35:235-42. PMID: 18423244 DOI: $10.1016 / \mathrm{j}$. ucl.2008.01.008

Higgins HM, Green LE, Green MJ, Kaler J. How does reviewing the evidence change veterinary surgeons' beliefs regarding the treatment of ovine footrot? A quantitative and qualitative study. PLoS One. 2013;8:e64175. PMID: 23696869 DOI: 10.1371/journal.pone.0064175

Lensen SF, Manders M, Nastri CO, Gibreel A, Martins WP, Templer GE, Farquhar C. Endometrial injury for pregnancy following sexual intercourse or intrauterine insemination. Cochrane Database Syst Rev. 2016;6:CD011424. PMID: 27296541 DOI: 10.1002/14651858.CD011424.pub2

Li R, Hao G. Local injury to the endometrium: its effect on implantation. Curr Opin Obstet Gynecol. 2009;21:236-9. PMID: 19352180 DOI: 10.1097/ GCO.0b013e32832a0654

Maia-Filho VO, Rocha AM, Ferreira FP, Bonetti TC, Serafini P, Motta EL. Matrix metalloproteinases 2 and 9 and e-cadherin expression in the endometrium during the implantation window of infertile women before in vitro fertilization treatment. Reprod Sci. 2015;22:416-22. PMID: 24700054 DOI: $10.1177 / 1933719114529373$

Martins WP. Assessment of endometrial volume by three-dimensional ultrasound in assisted reproduction procedures [Thesis]. Ribeirão Preto: Faculty of Medicine of Ribeirão Preto, University of São Paulo; 2007.

Nácul AP, Spritzer PM. Current Aspects on Diagnosis and Treatment of Endometriosis. Rev Bras Ginecol Obstet. 2010;32:298-307. DOI: 10.1590/S010072032010000600008

Nagy Z, Liu J, Cecile J, Silver S, Devroey P, Van Steirteghem A. Using ejaculated, fresh, and frozen-thawed epididymal and testicular spermatozoa gives rise to comparable results after intracytoplasmic sperm injection. Fertil Steril. 1995;63:808-15. PMID: 7890067 DOI: 10.1016/ S0015-0282(16)57486-X

Nardelli AA, Stafinski T, Motan T, Klein K, Menon D. Assisted reproductive technologies (ARTs): evaluation of evidence to support public policy development. Reprod Health. 2014;11:76. PMID: 25376649 doi: 10.1186/17424755-11-76 
Nastri CO, Gibreel A, Raine-Fenning N, Maheshwari A, Ferriani RA, Bhattacharya S, Martins WP. Endometrial injury in women undergoing assisted reproductive techniques. Cochrane Database Syst Rev. 2012;(7):CD009517. PMID: 25803542 DOI: 10.1002/14651858.CD009517.pub3

Nastri CO, Ferriani RA, Raine-Fenning N, Martins WP. Endometrial scratching performed in the non-transfer cycle and outcome of assisted reproduction: a randomized controlled trial. Ultrasound Obstet Gynecol. 2013;42:375-82. PMID: 23754314 DOI: $10.1002 /$ uog.12539

Pasqualotto F, Rossi-Ferragut $L$, Rocha CC, Iaconelli A Jr, Ortiz V, Borges E Jr. The efficacy of repeat percutaneous epididymal sperm aspiration procedures. J Urol. 2003;69:1779-81. PMID: 12686832 DOI: 10.1097/01. ju.0000066849.32466.2b

Pasqualotto FF, Rossi LM, Guilherme P, Ortiz V, Iaconelli A Jr, Borges $E$ Jr. Etiology-specific outcomes of intracytoplasmic sperm injection in azoospermic patients. Fertil Steril. 2005;83:606-11. PMID: 15749488 DOI: 10.1016/j.fertnstert.2004.08.033

Pasqualotto FF, Braga DP, Figueira RC, Setti AS, Iaconelli A Jr, Borges E Jr. Varicocelectomy Does Not Impact Pregnancy Outcomes Following Intracytoplasmic Sperm Injection Procedures. J Androl. 2012;33:239-43. PMID: 21474792 DOI: $10.2164 /$ jandrol.110.011932

Picinato MC, Martins WP, Giorgenon RC, Santos CK, Ferriani RA, Navarro PA, de Sá Rosa-e-Silva AC. The impact of examining the meiotic spindle by polarization microscopy on assisted reproduction outcomes. Fertil Steril. 2014;101:379-84. PMID: 24220701 DOI: 10.1016/j.fertnstert.2013.10.009

Pinheiro OL, Cavagna M, Baruffi RL, Mauri AL, Petersen C, Franco JG Jr. Administration of beta2-adrenergic agonists during the peri-implantation period does not improve implantation or pregnancy rates in intracytoplasmic sperm injection (ICSI) cycles. J Assist Reprod Genet. 2003;20:513-6. PMID: 15035551 DOI: 10.1023/b:jarg.0000013652.17193.38

Romão GS, Araújo MC, de Melo AS, Navarro PAAS, Ferriani RA, dos Reis RM. Oocyte diameter as a predictor of fertilization and embryo quality in assisted reproduction cycles. Fertil Steril. 2010;93:621-5. PMID: 19423095 DOI: 10.1016/j.fertnstert.2008.12.124

Santana LF, Ferriani RA, de Sá MF, dos Reis RM. Treatment of infertility in women with polycystic ovary syndrome. Rev Bras Ginecol Obstet. 2008;30:201-9. PMID: 19142493 DOI: $10.1590 / s 0100-72032008000400008$

Santos MFO. Intracytoplasmatic sperm injection: ethical and legal questions. Rev Bras Saúde Matern Infant. 2010;10:S289-S296.

SART. Society for Assisted Reproductive Technology; 2019. Available at: https://www.sart.org
Scheffer JB, Scheffer BB, de Carvalho RF, Rodrigues J, Grynberg M, Mendez Lozano DH. Age as A Predictor of Embryo Quality Regardless of The Quantitative Ovarian Response. Int J Fertil Steril. 2017;11:40-6. PMID: 28367304 DOI: $10.22074 /$ ijfs.2016.4579

Semião-Francisco L, Braga DP, Figueira RC, Madaschi C, Pasqualotto FF, Iaconelli A Jr, Borges E Jr. Assisted reproductive technology outcomes in azoospermic men: 10 years of experience with surgical sperm retrieval. Aging Male. 2010;13:44-50. PMID: 20121463 DOI: $10.3109 / 13685530903342203$

Sermondade N, Hafhouf E, Dupont C, Bechoua S, Palacios C, Eustache F, Poncelet C, Benzacken B, Lévy R, Sifer C. Successful childbirth after intracytoplasmic morphologically selected sperm injection without assisted oocyte activation in a patient with globozoospermia. Hum Reprod. 2011;26:2944-9. PMID: 21857011 DOI: 10.1093/humrep/der258

Setti AS, Braga DP, Figueira RC, Azevedo MC, Iaconelli A Jr, Borges E Jr. Are poor responders patients at higher risk for producing aneuploid embryos in vitro? J Assist Reprod Genet. 2011;28:399-404. PMID: 21110079 DOI: 10.1007/ s10815-010-9516-2

SisEmbrio - National System of Embryo Production. 120 Relatório do Sistema Nacional de Produção de Embriões. Brasília: Ministry of Health; 2019. Available at: http://portal.anvisa.gov.br/publicacoes?tagsName $=$ sisembrio

Souza AL, Sampaio M, Noronha GB, Coster LG, de Oliveira RS, Geber S. Effect of follicular flushing on reproductive outcomes in patients with poor ovarian response undergoing assisted reproductive technology. J Assist Reprod Genet. 2017;34:1353-7. PMID: 28733801 DOI: 10.1007/ s10815-017-0991-6

Sunkara SK, Rittenberg V, Raine-Fenning N, Bhattacharya S, Zamora J, Coomarasamy A. Association between the number of eggs and live birth in IVF treatment: an analysis of 400135 treatment cycles. Hum Reprod. 2011;26:176874. PMID: 21558332 DOI: 10.1093/humrep/der106

Taitson PF, Melo CS, Mancebo AC, Melo UB, Souza MC. Pregnancy after percutaneous epididymal sperm aspiration in an 81-year-old man with obstructive azoospermia. Andrology. 2012;44:355-7. PMID: 22385155 DOI: 10.1111/j.1439-0272.2012.01287.x

Tan J, Kan A, Hitkari J, Taylor B, Tallon N, Warraich G, Nakhuda $G$. The role of the endometrial receptivity array (ERA) in patients who have failed euploid embryo transfers. J Assist Reprod Genet. 2018;35:683-92. PMID: 29327111 DOI: $10.1007 / \mathrm{s} 10815-017-1112-2$

Teixeira DM, Hadyme Miyague A, Barbosa MA, Navarro PA, Raine-Fenning N, Nastri CO, Martins WP. Regular (ICSI) versus ultra-high magnification (IMSI) sperm selection for assisted reproduction. Cochrane Database Syst Rev. 2020;2:CD010167. PMID: 32083321 DOI: 10.1002/14651858.CD010167.pub3 
Valle M, Guimarães F, Cavagnoli M, Sampaio M, Geber $S$. Birth of normal infants after transfer of embryos that were twice vitrified/warmed at cleavage stages: report of two cases. Cryobiology. 2012;65:332-4. PMID: 22728047 DOI: $10.1016 /$ j.cryobiol.2012.05.012

Vieira M, Borges JS, Glina S. Infertilidade masculina. In: Lopes AC. Tratado de Clínica Médica. São Paulo: Rocca; 2009. p. 2964-72.

WHO - World Health Organization. Assisted Reproductive Technologies (ARTs). Geneva: WHO; 2019. Available at: Available at: https://www.who.int/genomics/gender/en/ index6.html. Accessed 2019 May 5.
Zegers-Hochschild F, Adamson GD, Dyer S, Racowsky C, de Mouzon J, Sokol R, Rienzi L, Sunde A, Schmidt L, Cooke ID, Simpson JL, Van Der Poel S. The International Glossary on Infertility and Fertility Care, 2017. Fertil Steril. 2017;108:393-406. PMID: 28760517 DOI: 10.1016/j. fertnstert.2017.06.005

Zeqiraj A, Beadini S, Beadini N, Aliu H, Gashi Z, Elezaj S, Bexheti S, Shabani A. Male Infertility and Sperm DNA Fragmentation. Open Access Maced J Med Sci. 2018;6:1342-5. PMID: 30159053 DOI: 10.3889/oamjms.2018.311 


\begin{tabular}{|c|c|}
\hline Database & Keywords \\
\hline Pubmed & $\begin{array}{l}\text { "Assisted Reproductive Technology" AND "Brazil"; "Assisted Reproductive } \\
\text { Technologies" AND "Brazil"; "Assisted Reproductive Technique" AND } \\
\text { "Brazil"; "Assisted Reproductive Techniques" AND "Brazil"; "Assisted } \\
\text { Reproductive Technic" AND "Brazil"; "Assisted Reproductive Technics" } \\
\text { AND "Brazil". }\end{array}$ \\
\hline Scopus & $\begin{array}{l}\text { "Assisted Reproductive Technology" OR "Assisted Reproductive } \\
\text { Technologies" AND "Brazil"; "Assisted Reproductive Technique" or } \\
\text { "Assisted Reproductive Techniques" AND "Brazil" "Assisted Reproductive } \\
\text { Technology" OR "Assisted Reproductive Technologies" AND "Brazil"; } \\
\text { "Assisted Reproductive Technic" OR "Assisted Reproductive Technics" } \\
\text { AND "Brazil". }\end{array}$ \\
\hline Web of Science & "Assisted Reproductive Techniques" AND "Brazil". \\
\hline LILACS & $\begin{array}{l}\text { "Assisted Reproductive Technique" OR "Técnicas Reproductivas Asistidas" } \\
\text { OR "TécnicasdeReproduçãoAssistida"AND"Brazil"; "Assisted Reproductive } \\
\text { Techniques" OR "Técnicas Reproductivas Asistidas" OR "Técnicas de } \\
\text { Reprodução Assistida" AND "Brazil"; "Assisted Reproductive Technic" } \\
\text { OR "Técnicas Reproductivas Asistidas" OR "Técnicas de Reprodução } \\
\text { Assistida" AND "Brazil"; "Assisted Reproductive Technics" OR "Técnicas } \\
\text { Reproductivas Asistidas" OR "Técnicas de Reprodução Assistida" AND } \\
\text { "Brazil"; "Assisted Reproductive Technology" OR "Técnicas Reproductivas } \\
\text { Asistidas" OR "Técnicas de Reprodução Assistida" AND "Brazil"; "Assisted } \\
\text { Reproductive Technologies" OR "Técnicas Reproductivas Asistidas" OR } \\
\text { "Técnicas de Reprodução Assistida" AND "Brazil". }\end{array}$ \\
\hline Google Scholar & "Assisted reproductive techniques" AND "Brazil". \\
\hline Open Grey & $\begin{array}{l}\text { "Assisted Reproductive Technique" OR "Assisted Reproductive Techniques" } \\
\text { AND "Brazil"; "Assisted Reproductive Technic" OR "Assisted Reproductive } \\
\text { Technics" AND "Brazil"; "Assisted Reproductive Technology" OR "Assisted } \\
\text { Reproductive Technologies" AND "Brazil". }\end{array}$ \\
\hline
\end{tabular}

